$\varkappa$ Values for correct identification and interobserver agreement. Values in parentheses are proportions of ratings observed/expected to be in agreement; confidence intervals were based on 1500 bootstrap samples

\begin{tabular}{lll}
\hline & Correct identification & \multicolumn{1}{c}{$\begin{array}{c}\text { Interobserver } \\
\text { agreement }\end{array}$} \\
\hline Sex & $+0.0625(0.531 / 0.500)$ & $+0.0116(0.506 / 0.500)$ \\
$95 \%$ Confidence interval: & -0.070 to 0.072 & -0.134 to 0.158 \\
$\quad$ Fixed observer & -0.092 to 0.089 & -0.096 to 0.312 \\
Random observer & $+0.005(0.0875 / 0.0833)$ & $-0.007(0.0777 / 0.0841)$ \\
Star sign & -0.024 to 0.026 & -0.012 to 0.085 \\
95\% Confidence interval: & -0.060 to 0.223 \\
\hline
\end{tabular}

chance agreement, and negative values indicate disagreement.

The table shows the extent that observers were correct and the interobserver agreement.

\section{Comment}

The results of this study show that the likelihood of this particular group of pathologists or pathologists in general being capable of divining the sex or star sign of a patient, even with recourse to the perception of light, is no greater than chance. From this it is reasonable to deduce that pathologists do not possess extrasensory perception, at least as far as medical practice is concerned.

In the light of these findings clinical practice should now radically alter. We strongly recommend that physicians, surgeons, and other users of histopathological services change their current practice and provide full clinical information on all request forms.

We thank our colleagues in the department of pathology, Sheffield University Medical School, for their help in this research.

\footnotetext{
Underwood JCE. Introduction to biopsy interpretation and surgical pathology. London: Springer-Verlag, 1987:2-3.

Lyons AS, Petrucelli RJ. Medicine: an illustrated history. New York: Abrams, 1987:583.

3 Light RJ. Measures of response agreement: some generalisations and alternatives. Psychol Bull 1971;76:365-77.

4 Fleiss JL. Statistical methods for rates and proportions. 2nd ed. New York: John Wiley, 1981:230.

5 Diaconis P, Efron B. Computer intensive methods in statistics. Sci Am 1983;248(5):6-108.
}

\title{
How to have a fever of unknown origin
}

Miles Burrows

I was working in the Middle East and had never felt so fit in my life. I played tennis in the warm nights under the floodlights and in the day swam up and down the pool like a trout in a restaurant. I even gave myself extra pocket money by donating my blood for the blood transfusion service.

When one day they told me that they could not accept my blood I felt a little offended-rather as an author would feel if his poems were rejected by a magazine, but otherwise I thought nothing of it. I went on swimming up and down the pool. But I got messages that there was something wrong with my white cells. They kept going down.

I was feeling so well that again I thought nothing of it, even felt that having a low white count could be a sign of being superfit, like having a slow pulse. Then I started feeling rather tired and even found it difficult to stand for long periods, especially in the hot sun waiting for the bus to the hospital. I would hunker down under the pipul tree like a Pathan gardener. At nights I was woken by the sound of the bedhead knocking against the wall. This was not a wet dream, but it was caused by my heart beating rapidly and strongly as I slept. Every time I checked my white cells they had gone further down. When other doctors told me to take this seriously I saw the haematologist.

He was an American. He told me that the white cells looked as if they were turned on. I was impressed by the phrase "turned on," which sounded up to date, even hip. He said that he was going on holiday, that these things could be caused by a virus, so we should wait. I agreed, but felt weaker and weaker.

I consulted a general physician, who agreed with me that this could be a "leukaemic process." He did a sternal marrow tap in my own consulting room in the hospital in the lunch break. I was spreadeagled on the couch with the needle aimed far too close to the heart. When the result came back - "a dry tap"-this confirmed our fears. I went upstairs, where the oncologist did a biopsy of the iliac crest. I waited numbly for the pathologist's report, like a man doing a crossword while his plane is crashing. When the result came back as normal I was astonished. But we had to suppose that that ruled out leukaemia.

\section{Loss of weight}

When it was time to go back to England on holiday I could hardly carry my backpack. I sat in a window seat on the plane warming myself in the sunlight like a fly, and refused to give up my seat for a child. When my wife saw me she hardly recognised me. I had lost $10 \mathrm{~kg}$. I went to my general practitioner and told him I thought I should go to hospital as an emergency. He agreed and asked me if I wanted to go in under oncology or infectious diseases. I already had a letter in my pocket that I had written to the professor of haematology or oncology, but then thought why not try infectious diseases?

I went into the infectious diseases unit through a decontamination area like something out of a space shuttle. Everyone was wearing masks so they couldn't catch whatever it was I had got. It made them look like symbolic figures in a Japanese play. They gave me quinine for malaria. It was the consultant's doctrine that all exotic fevers were caused by malaria.

$\mathrm{My}$ fevers rose to $40^{\circ} \mathrm{C}$ at night and I was sweating like an Ascot winner. The registrar would come in and say, "You had an impressive fever last night," as if congratulating me on having hit a six. They tested for brucellosis and asked if I had been drinking goat's milk.

I drank aniseed flavoured dyes and was pushed around in a wheelchair at high speed from one scanner to the next, feeling like an elderly art critic being wheeled round an exhibition just before the deadline for his copy - the corridors were hung with attractive original paintings. At the back of my mind I was worried that I had some form of AIDS and I mentioned this to the consultant. AIDS had already been screened out in the Middle East, but I kept thinking of that time in Bangkok. That girl who rode a water buffalo in high heeled shoes. I remembered trying to persuade her to wear sensible shoes. I thought of her as I looked out of the locked fire escape on the ninth floor. When after a 
week the AIDS test came back as negative I thanked God and didn't know I cared so much about respectability.

There was an irritating draught coming in through the door and I asked the sister to do something about it . She said that if I was worried about the draught I could always go into the general ward. That shut me up. But she did compromise by hanging a blanket over the door like some amateur theatrical device. I never knew who was going to come in through the curtain, the consultant or the cleaning lady. "Still here, are you?" the cleaning lady asked, as if I was a guest overstaying his welcome at a party.

\section{Scraping the barrel}

Obviously with these infectious diseases most people were in and out in a flash. But I stayed six weeks. I had everything from computed tomography to cardiac ultrasound. I felt they were scraping the barrel and beginning to lose interest.

The senior registrar said, "Sometimes with these fevers of unknown origin you never find the answer."

"Never?" I asked hysterically. "You mean until the necropsy?"

I was so weak I could hardly turn over in bed. I was giving off a horrible smell at night. The night sister kept wanting to wash my back. The senior registrar did a biopsy of the liver and I nearly hit the ceiling. Then the consultant came in and said, "We're thinking about taking out your spleen."

I felt defensive about my spleen. It was an essential component of a romantic poet. I said that I wanted to keep it. He said that he just wanted to do a biopsy but, "You know what these surgeons are like: once they are in there they will have it out even if I stand in the theatre holding on to his arm."

They compromised by taking a tiny node out of my axilla. The consultant said that he was sending me home for a couple of weeks and that I must be patient. I must give them time to reflect and reconsider. I must give them some dream time. Dream time? I had never thought of the consultant as an Australian Aborigine before.

I went home and lay on the sofa and read books on anthropology like a Victorian woman with green sickness. I looked at the bare breasted girls of the Sudan smoking pipes. When I got back to the hospital the young house surgeon-with whom I had fallen hopelessly in love-told me that the first report about the axillary node biopsy was incomplete. She had read only the first page. Later, on turning over and reading the second page, she saw that the pathology professor, who liked to keep his surprises till the end like a classical short story writer, had finally mentioned in a throwaway line that the biopsy specimen was highly suspicious of lymphoma.

I was not quite sure what lymphoma signified so asked the house surgeon, who trotted out "A tumour of the reticuloendothelial system," just as I used to. But if it was a tumour why had nothing swollen up? Why had the cells gone down? I didn't like to ask. Then a specialist in lymphoma came in. He was quite certain that that was what I had. He would start appropriate treatment.

That same night a new registrar came in and introduced himself as if it was a cocktail party. I responded irritably. I was having such violent rigors that he had difficulty getting the needle into the vein to infuse the cytotoxic drugs.

"I'm amazed if this is lymphoma," he said.

When the drugs started to go in, I had difficulty breathing and rang for the night nurse, who gave me a paper bag to breathe into.

\section{Hairless like a Greek statue}

But next morning I was already feeling a lot better and left the hospital to return once a week for 12 weeks All my hair fell out, including the pubic hair, so that I felt like an elderly Greek statue. But I put on weigh and after three months was well enough to fly back to the Middle East.

The American haematologist was astonished by the biopsy report and said that there was not enough evidence for lymphoma.

"Those were heavy duty drugs," he said.

"But they saved my life. I was dying."

"In the United States," he said, "we could never have done that. You'd have sued the pants off us."

I thanked God for the NHS.

The American is still not convinced. The only way that I can prove him wrong is by having a relapse and I have no intention of doing that.

My hair grew again, bushier than ever. One day I was approached by a bald Pakistani hospital porter in the lift; he wanted to know what I had been using as a hair restorer.

\title{
Give a drug a bad name
}

\author{
D B Jack, A J Soppitt
}

\section{Fidia Research Laboratories, 35031 Abano Terme, Padua, Italy D B Jack, PHD, head, scientific information service}

\section{Department of} Gastroenterology, Dudley Road Hospital, Birmingham A J Soppitt, MB

Correspondence to: Dr Jack.

BMF 1991;303:1606-8

\begin{abstract}
"Yossarian? What the hell kind of a name is Yossarian?" Lieutenant Scheisskopf had the facts at his fingertips. "It's Yossarian's name, sir," he explained.'
\end{abstract}

Just as everyone and everything have to be somewhere in this world, everyone and everything have to be called something. We need labels. In the commercial world, names are supremely important because they don't just identify a product; they can create an image.

If a name can be registered by a company it becomes the company's property and any infringement can be challenged in court. Some names, such as family and geographical names, cannot be registered-which explains why, in the United Kingdom, a "Montego" could be a car or a chocolate biscuit. One trade name failed to get registered when someone discovered it was the name of a Zulu tribe.
Choosing the "right" name can greatly help the marketing of a product, and although opinions vary as to what constitutes a good name, the Jazz range of toiletries for men launched a few years ago by Yves St Laurent must surely be a prime example. The name "Jazz" can be recognised throughout the world; it has hip and sophisticated connotations; the product is sold in smart black and white angular bottles (it smells nice, too).

As might be expected, state monopolies do things rather differently. There is the story of an aftershave in the Soviet Union, sold under a name that could be translated as "Dear Friend," that failed miserably possibly because homosexuality is still illegal there. The Russians fared no better with the perfume "Anna Karenina," which might seem surprising as they are a cultured people and Tolstoy is one of their favourite 